\title{
Soil Quality in Agroecological Production Areas in Southern Brazil: Indicators Based on Farmers' Perception
}

Jacir João Chies

Family Agricultural Production Systems Program, Federal University of Pelotas Campus s/n, Capão do Leão, Brazil, E-mail: jacirchies@yahoo.com.br

\section{Helvio Debli Casalinho}

Soil Department, Faculty of Agronomy Eliseu Maciel, Federal University of Pelotas Campus s/n, Capão do Leão, Brazil, E-mail: hdc1049@gmail.com

\section{Lizete Stumpf (Corresponding author)}

Soil Department, Faculty of Agronomy Eliseu Maciel, Federal University of Pelotas Campus s/n, Capão do Leão, Brazil, E-mail: zete.stumpf@gmail.com

\section{Marília Alves Brito Pinto}

Center of Technological Development, Federal University of Pelotas Gomes Carneiro St. 01, Pelotas, Brazil, E-mail: ma.agro@gmail.com

\section{Leonir Aldrigui Dutra Junior}

Soil and Water Management and Conservation Program, Federal University of Pelotas Campus s/n, Capão do Leão, Brazil, E-mail: leonirdutrajr@gmail.com

Received: January 22, 2021 doi:10.5296/jas.v9i2.18230
Accepted: February 24, 2021 Published: March 8, 2021 URL: https://doi.org/10.5296/jas.v9i2.18230 


\section{Abstract}

Farmers' local knowledge about soil quality and management practices should be considered to assess the impact of agricultural technology packages on the environmental performance of agro-ecosystems. This study aimed to evaluate the soil quality under agroecological production in southern Brazil, which was considered of good quality by the farmers' perception. From August to November 2017, ten farms from Liberdade settlement were visited, and semi-structured interviews were conducted to collect information about soil and agricultural knowledge. "What does good quality soil mean? What cares for preserve soil quality? Does the soil location in landscape influence conservation practices?" were the questions asked. In May 2018, soil samples were collected from each area, and chemical, physical, and biological attributes were determined. All farmers mentioned the organic matter indicated good soil quality; however, the study showed that most soils have low content, a consequence of the annual tillage adopted by all farmers for the implantation of seeds crops; Farmers indicated that a good quality soil has "life" with the presence of organisms. In our study, a low population of mites and springtails in most areas was observed. Positive farmers' perception about the organic matter content and soil organism's presence in their agroecological production areas come from the degradation history of the areas, at the same time that they attribute improvements in soil quality due to the actions adopted over the 10 years of agroecological production.

Keywords: organic matter, mites and springtails population, bulk density, annual tillage, cover crops

\section{Introduction}

The Farmers' local knowledge about soil quality and management practices should be considered to better assess the impact of agricultural technology packages on the socio-economic and environmental performance of agro-ecosystems (Kuria et al. 2018; Morshedi et al. 2017; Tesfahunegn et al. 2016; Mairura et al. 2007; Bellon \& Taylor, 1993).

Farmers' field experience is an entry point to soil quality assessment at the regional level, especially in regions with limited resources (Prudat et al. 2018). About that, Buthelezi-Dube et al. (2019) revealed that local qualitative soil fertility knowledge of farmers links to crop performance and potentially supports laboratory soil analysis for smallholder agriculture in eastern South Africa. Adeyolanu et al. (2018) showed also that farmers' perception of soil quality and soil scientists correlate well, i.e., farmers' perception identified compaction, erosion, low soil fertility as a result of low nutrient availability and retention, termite infestation, poor drainage, flooding, high land-use intensity without proper management and all these have the resultant effect of decreased crop yield or low productivity in Southwestern Nigeria.

According to Barrera-Bassols et al. (2006) merging technical and local thinking is indispensable to formulate sustainable land management schemes, and that ethnopedology can help validate scientific soil knowledge to assure that it is not only scientific but also relevant and functional for agroecosystems. Finally, Yageta et al. (2019) highlight spatial 
location is an important consideration in farmers' evaluations, reflecting awareness of local diversity in soil and historical social or environmental factors.

In Brazil, farmers' local knowledge is more valued in research with agroecological production units. Agroecology studies agricultural activity from an ecological perspective, adopting the agroecosystem as a unit of analysis, aiming to provide the scientific bases to support the transition process from the current model of conventional agriculture to more sustainable farming (Altieri, 2002). The agroecological transition also is a social process, which searches to change the attitudes and values of social actors concerning natural resources management and conservation, and an economic-productive rationalization based on the biophysical specificities of each agroecosystem (Caporal \& Costabeber, 2004). In turn, farmers' perceptions of soil quality and its indicators are fundamental elements in research with family farmers that are in the process of transition to ecologically agriculture (Casalinho et al. 2017), converging with the considerations of Lal (2015), who emphasizes that factors specific to the location (biophysical, social, economic, cultural) are significant in soil quality monitoring and management changes.

In Southern Brazil, agrarian reform settlers develop collective or individual agricultural activities linked to BIONATUR Network, a pioneering experience in Latin America directed to the production and commercialization of agroecological seeds, which involves around one hundred and sixty families in the Rio Grande do Sul state (Southern Brazil). Therefore, the study aimed to evaluate the soil quality under agroecological production in southern Brazil, which was considered of good quality by the farmers' perception.

\section{Method}

\subsection{Settled Farmers Selection and Study Area}

The BIONATUR Network is comprised of around one hundred and sixty settled farmer's families in Brazil with an annual production of twenty tons of vegetable, ornamental, and grain seeds (Silva et al. 2014). In the Rio Grande do Sul State, Southern Brazil, ten families participate in the Association of Ecological Producers of the Conquista da Liberdade settlement - APECOL (Latitude 31 $26^{\prime} 15^{\prime \prime}$ and Longitude 5306 $15^{\prime \prime}$ ), which produce creole seeds with organic certification.

In August 2017, a meeting was held at APECOL with the participation of the associated settlers and the technical teams that accompany the association, for the discussion and definition of the research theme. Among the various topics listed, the participants stated that the research should focus on the soil quality diagnosis in the areas of agroecological seed production. Besides tiling the research theme, the study participants were also defined which would include all of the associated farmers, a total population of ten families with land dimensions around 20 to 25 hectares. In all ten areas, the seed agroecological production was adopted for at least 10 years.

The soil predominantly in the ten farms was classified as Argissolo Vermelho Amarelo according to the Brazilian Soil Classification System (Santos et al. 2013), which corresponds to Ultisols based on Soil Survey Staff (2014). The climate is classified as Cfa, with an 
average annual air temperature between 16 and $18{ }^{\circ} \mathrm{C}$ and average annual precipitation between 1,600 and 1,900 mm (Alvares et al. 2013).

\subsection{Assessment of Settled Farmers' Knowledge}

From August to November 2017, ten farms were visited, and semi-structured interviews were conducted to collect farmer's information about soil and agricultural knowledge. Although scheduled, two families were not available for the interview.

Interviews were held in the house, and in front of agricultural soils, providing locational references. Therefore, history and current management practices were collected in all agricultural areas, and the main information includes: (a) soil liming performed for at least 2 years; (b) organic fertilization with poultry litter and/or biofertilizers applied annually; (c) cover crops in the winter season and/or the soil is not under seed production; (d) management of spontaneous plants with a hoe and/or plow with animal traction; (e) insect and disease management using repellents, and biofertilizers; (f) manual harvesting of seed crops; and (g) tillage type with a harrow.

After describing the area's history, questions about soil quality and management were asked: (1) What does good quality soil mean? What cares for preserve soil quality? (3) Does the soil location in landscape influence conservation practices? Results transcription and systematization obtained from the farmer's interviews were developed according to the methodology of Bardin (2004). The main soil quality indicators addressed in farmer's perceptions were associated with soil attributes analysis measured. i.e. (1) organic matter and "full-bodied" soil were adequate to soil organic matter and soil nutrient content; (2) impacted, hard and loose soil was adequate to bulk density determination; (3) acid soil was adequate to soil $\mathrm{pH}$; (4) shallow or depth soil, and clay thickness was adequate to A horizon depth and clay content; (5) soil moisture and water infiltration were adequate to soil porosity; (6) little insects, soil life, beetles were adequate to the population of mites, and springtails determination (Table 1).

\subsection{Assessment of Soil Quality Indicators}

In May 2018, soil samples from ten areas under seed agroecological production were collected. Areas were identified as L1, L2, L3, L4, L5, L6, L7, L8, L9 e L10. The seeds produced in the agricultural year of 2017/2018 were beans (Phaseolus vulgaris) in L1, L3, L6, L8 areas, corn (Zea mays) in L5, L7, L9 areas, flaxseed (Linum usitatissimum) in the L2 area, and vegetables in general (Cucurbita spp.; Coriandrum sativum; Daucus carota; Brassica alba; Allium cepa) in L3, L4, L10 areas.

Soil samples from the native forest were also collected as a reference area. The native forest is part of the settlement's legal reserve with the predominance of tree species such as Scutia buxifolia, Vachellia caven, and Prosopis nigra, and is located next to all agricultural areas of the study. 


\section{Macrothink Institute ${ }^{\mathrm{TM}}$}

Table 1. Choice of soil attributes for laboratory determination based on farmers' responses to their perceptions of what good quality soil means

Settled farmers expressions

1. organic matter, "full-bodied" soil

2. impacted soil, hard soil, loose

3. acid soil

4. shallow or depth soil, clay thickness

5. soil moisture, water infiltration

6. little insects, soil life, beetles
Academic expressions

1. soil organic matter/nutrient content

2. compaction/bulk density

3. soil $\mathrm{pH}$

4. depth A horizon/clay content

5. soil porosity

6. mites, springtails, other organisms

In the 0.00-0.20m layer from each agricultural and reference area was collected:

(a) Depth of the soil A horizon;

(b) Three soil samples with a non-preserved structure to determine clay content, soil $\mathrm{pH}$, calcium, magnesium, potassium, phosphorus, and organic matter content, according to Tedesco et al. (1995) methodology;

(c) Three soil samples with a preserved structure to determine soil bulk density, total porosity, macroporosity, and microporosity by Embrapa (2011) methodology, using $0.050 \mathrm{~m}$ length and $0.047 \mathrm{~m}$ diameter stainless steel cylinders.

(d) Three soil samples with a preserved structure to determine edaphic mesofauna organisms, using $0.08 \mathrm{~m}$ length and $0.085 \mathrm{~m}$ diameter stainless steel cylinders. The number of individuals was calculated according to the Funnel Extractor method of Tullgren, proposed by Bachelier (1978).

Soil quality was evaluated using the average data of chemical indicators which were classified according to the Soil Chemistry and Fertility Commission (CQFS, 2016); and the mean values of physical and biological indicators that were related to the critical values found in the literature.

To group and evaluate the relationship between the indicators, as well as their relationship with the soil quality of the ten areas under agroecological production and the native forest, the principal component analysis (PCA) was applied. PCA is based on the correlation matrix between the components and the variables studied. 


\section{Results}

\subsection{Soil Quality Status From Settled Farmers' Knowledge}

The main farmers' perceptions about "good soil quality" question were: Soil with good organic matter content and/or dark color (seven families); Uncompressed soil (five families); Non-acidic soil (four families); Soil with good effective depth and without clay horizon (three families); Soil with good water infiltration and moisture conservation (six families); Soil with earthworms and other organisms present (seven families). The farmers' answers supported the choice of soil attributes measured in the laboratory, with the appropriate adjustments, as mentioned in Table 1.

The main answers about the care taken to preserve soil quality and if farmers consider the soil position in the landscape for the conservation practices adoption were: Soils in hill slopes are more susceptible to erosion, so an intense tillage control should be used (five families); Degraded soils should intensify use cover crops and organic fertilization (five families); In lowland areas, crops are avoided during the winter season due to soil susceptibility to flooding (two families); In sandy soils should intensify use cover crops, and/or livestock should be avoided (two families); In clay soils crops are less susceptible to drought for longer periods (two families); Absence of earthworms in the soil is due to excessive pesticide use in previous crops (two families).

\subsection{Technical Soil Quality Assessment}

The soil samples for chemical, physical, and biological evaluations in all agroecological production areas covered horizon $\mathrm{A}$, which ranged between 0.23 to $0.50 \mathrm{~m}$ depth, and clay content was higher than $15 \%$ and less than $35 \%$ at $0.20 \mathrm{~m}$ depth (Figure 1). This means that soils in all agroecological seed production are susceptible to drought, and have low natural fertility if management practices that increase soil organic matter content are not adopted.

Although farmers indicate in their interviews that a quality soil must have organic matter and the cover crop practice must be adopted, the organic matter content was around $2.5 \%$ in most areas considered low for Southern Brazil soils (CQFS, 2016). In the native forest, the organic matter content was $3.2 \%$ (Table 2).

The most of agroecological seed production areas presented a soil $\mathrm{pH}$ of less than 6.0 considered inappropriate for vegetables, corn, and beans crops (CQFS, 2016). Despite low $\mathrm{pH}$ values, in table 2 we observed that soils under agricultural production did not yet have high aluminum saturation (ranged from 0 to $8.1 \%$ ). On the other hand, it was observed that most areas presented base saturation values of above $60 \%$, with high calcium and magnesium contents (CQFS, 2016), probably, effect to organic fertilization added annually. 


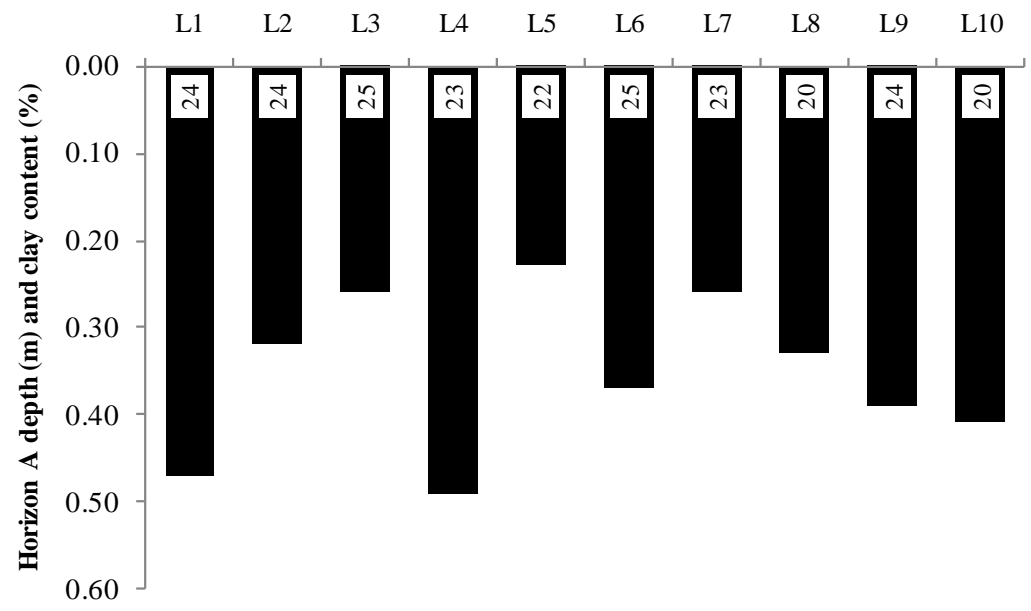

Figure 1. Horizon A depth and clay content at $0.20 \mathrm{~m}$ depth in the ten areas under agroecological seed production, identified as L1 to L10, and reference area (native forest) at Conquista da Liberdade Settlement, Southern Brazil

Table 2. Soil chemical attributes in the ten areas under agroecological seed production, identified as L1 to L10, and reference area (native forest) at Conquista da Liberdade Settlement, Southern Brazil ( $n=10 ; \pm$ standard deviation)

Areas under agroecological seed production

Reference

Native

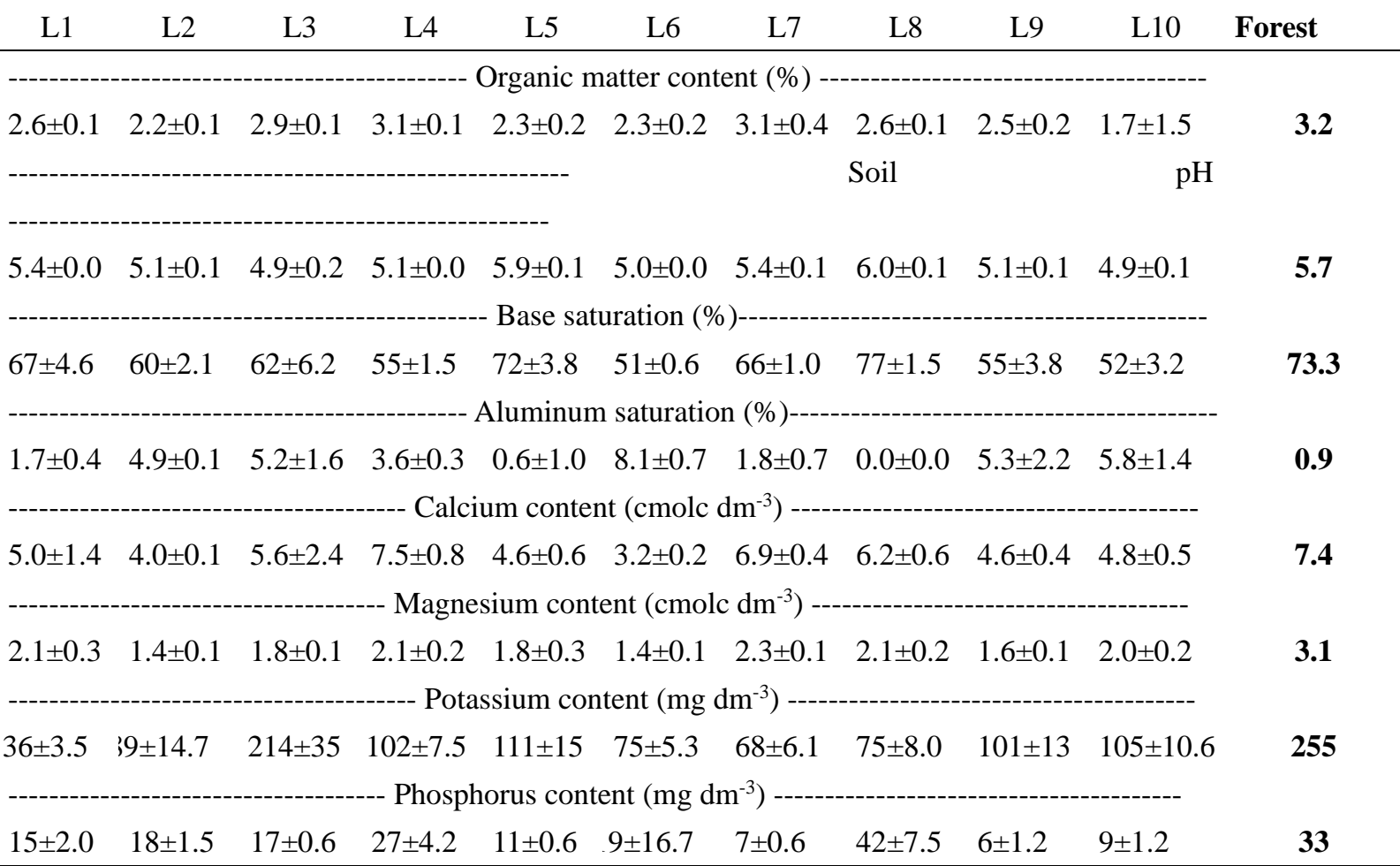

The soil $\mathrm{pH}$ in agroecological seed production areas was up to $13.4 \%$ lower than the native forest (5.7). In general, most of the agricultural areas presented lower base saturation than in the native forest area (up to $29.1 \%$ ). The high calcium and magnesium content in the native 
forest reflects the high nutrient recycling by plants.

In table 2 shows that potassium content in the soils ranged from very high (L3), high (L1, L5, L8, L9, L10), and medium (L2, L4, L6, L7), while the phosphorus content ranged from high (L4, L8), medium (L1, L2, L3, L6), low (L5, L7) and to very low (L9, L10) according to CQFS (2016).

In table 3, we observed all soils under agroecological seed production presented bulk density ranged from 1.23 to $1.38 \mathrm{Mg} \mathrm{m}^{-3}$, considered below the critical development for most crops on medium textural class soils, which is $1.55 \mathrm{Mg} \mathrm{m}^{-3}$ (Reichert et al., 2007). Total porosity in all areas was equal or higher $0.43 \mathrm{~m}^{3} \mathrm{~m}^{-3}$, considered appropriate for crops development (between 35 and $60 \%$, according to Khiel, 1979), with most soils showing 1/3 of their porous volume occupied by macroporosity, which was in most of the areas higher than $0.15 \mathrm{~m}^{3} \mathrm{~m}^{-3}$.

Table 3. Soil physical attributes in the ten areas under agroecological seed production, identified as L1 to L10, and reference area (native forest) at Conquista da Liberdade Settlement, Southern Brazil ( $n=10 ; \pm$ standard deviation)

\begin{tabular}{lccccc}
\hline Areas & $\begin{array}{c}\text { Bulk density } \\
\mathrm{Mg} \mathrm{m}^{-3}\end{array}$ & $\begin{array}{c}\text { Macroporosity } \\
\text { L1 }\end{array}$ & $\begin{array}{c}\text { Microporosity } \\
\text { Total porosity }\end{array}$ & Mi/Ma \\
\hline L2 & $1.24 \pm 0.20$ & $0.25 \pm 0.05$ & $0.24 \pm 0.02$ & $0.49 \pm 0.07$ & $1: 1$ \\
L3 & $1.38 \pm 0.12$ & $0.18 \pm 0.06$ & $0.25 \pm 0.03$ & $0.43 \pm 0.03$ & $1: 1$ \\
L4 & $1.32 \pm 0.06$ & $0.23 \pm 0.02$ & $0.26 \pm 0.02$ & $0.49 \pm 0.01$ & $1: 1$ \\
L5 & $1.23 \pm 0.04$ & $0.14 \pm 0.04$ & $0.31 \pm 0.03$ & $0.45 \pm 0.07$ & $2: 1$ \\
L6 & $1.36 \pm 0.13$ & $0.21 \pm 0.07$ & $0.25 \pm 0.02$ & $0.46 \pm 0.08$ & $1: 1$ \\
L7 & $1.38 \pm 0.15$ & $0.15 \pm 0.02$ & $0.28 \pm 0.02$ & $0.43 \pm 0.06$ & $2: 1$ \\
L8 & $1.24 \pm 0.13$ & $0.13 \pm 0.03$ & $0.37 \pm 0.03$ & $0.49 \pm 0.04$ & $3: 1$ \\
L9 & $1.33 \pm 0.07$ & $0.17 \pm 0.04$ & $0.29 \pm 0.04$ & $0.47 \pm 0.02$ & $2: 1$ \\
L10 & $1.30 \pm 0.09$ & $0.20 \pm 0.03$ & $0.26 \pm 0.01$ & $0.46 \pm 0.02$ & $1: 1$ \\
\hline Reference (Native Forest) & $1.34 \pm 0.06$ & $0.08 \pm 0.03$ & $0.38 \pm 0.03$ & $0.46 \pm 0.04$ & $5: 1$ \\
\hline
\end{tabular}

The microporosity ranged from 0.24 to $0.38 \mathrm{~m}^{3} \mathrm{~m}^{-3}$, and $\mathrm{Mi} / \mathrm{Ma}$ ratio observed in most of the areas was between 1:1 and 2:1 (Table 3), considered adequate for water storage and root aeration according to Lacerda Ribeiro et al. (2018). The high Mi/Ma ratio in area L10 is probably a consequence of the use of the area for grazing in the previous year.

Concerning the native forest, the soils under agroecological seed production presented between 52.4 to $60.8 \%$ higher bulk density, and between 22 to $75 \%$ lower macroporosity, and between 21.8 to $32.3 \%$ lower total porosity (Table 3 ). These results were expected since in natural ecosystems the soil reflects a state of balanced organization between climate, vegetation, topography, and inherent soil characteristics, which provide a continuous input of organic carbon and a structural condition without a history of load-bearing. However, this balanced state is altered when the soil is used for agricultural purposes, since carbon input and output become very influenced by soil tillage, and crop residue management (Campos et al. 2011). 
In table 4 showed some differences in the number of individuals of mites and springtails for ten areas analyzed. In the L1 (beans seed producer) and L2 (flaxseed seed producer) areas, the mites population was next or equal to ten individuals, while other areas (beans, corn, and vegetable seeds producer) presented less than five individuals. About the springtails population, the L8 area presented (beans seed producer) a hundred and seventy-six individuals, while L9 (corn seed producer) and L6 (beans seed producer) areas present sixteen and twenty individuals respectively, and others areas present less than ten individuals. When compared to the native forest area six areas under agroecological seed production had a smaller mites population and eight areas had a higher springtails population (Table 4).

Table 4. Soil edaphic mesofauna in the ten areas under agroecological seed production, identified as L1 to L10, and reference area (native forest) at Conquista da Liberdade Settlement, Southern Brazil ( $n=10 ; \pm$ standard deviation)

\begin{tabular}{lcc}
\hline Areas & Mites & Springtails \\
\hline L1 & $10.0 \pm 5.6$ & $8.7 \pm 3.8$ \\
L2 & $7.7 \pm 5.7$ & $6.0 \pm 2.6$ \\
L3 & $3.3 \pm 1.5$ & $5.0 \pm 2.0$ \\
L4 & $0.0 \pm 0.0$ & $0.0 \pm 0.0$ \\
L5 & $1.7 \pm 0.6$ & $3.3 \pm 4.9$ \\
L6 & $1.3 \pm 0.6$ & $16 \pm 15.1$ \\
L7 & $2.3 \pm 0.6$ & $8.0 \pm 6.0$ \\
L8 & $1.3 \pm 1.5$ & $174.7 \pm 182.4$ \\
L9 & $4.3 \pm 2.1$ & $20 \pm 25.4$ \\
L 10 & $1.0 \pm 1.7$ & $0.0 \pm 0.0$ \\
\hline Reference (Native Forest) & $\mathbf{3 . 3}$ & $\mathbf{1 . 3}$ \\
\hline
\end{tabular}

\subsection{Relationship Between Soil Quality Indicators and Soil Management}

In the principal component analysis between soil biological, chemical, and physical variables, the first two components were considered, which had accumulated an eigenvalue of $56 \%$. The two components resulted from the linear combination of 11 variables studied, the first explained $31.6 \%$ and the second $24.4 \%$ of the total variance.

The first component showed the highest positive correlation for $\mathrm{pH}$, base saturation, and phosphorus content, while negatively the aluminum saturation showed the highest correlation (Figure 2A). This component can be interpreted as a response related to soil acidity, since with the increase of $\mathrm{pH}$ and base saturation; there is a decrease of aluminum contents, possibly associated with the use of combined limestone with vegetable waste. 
A)

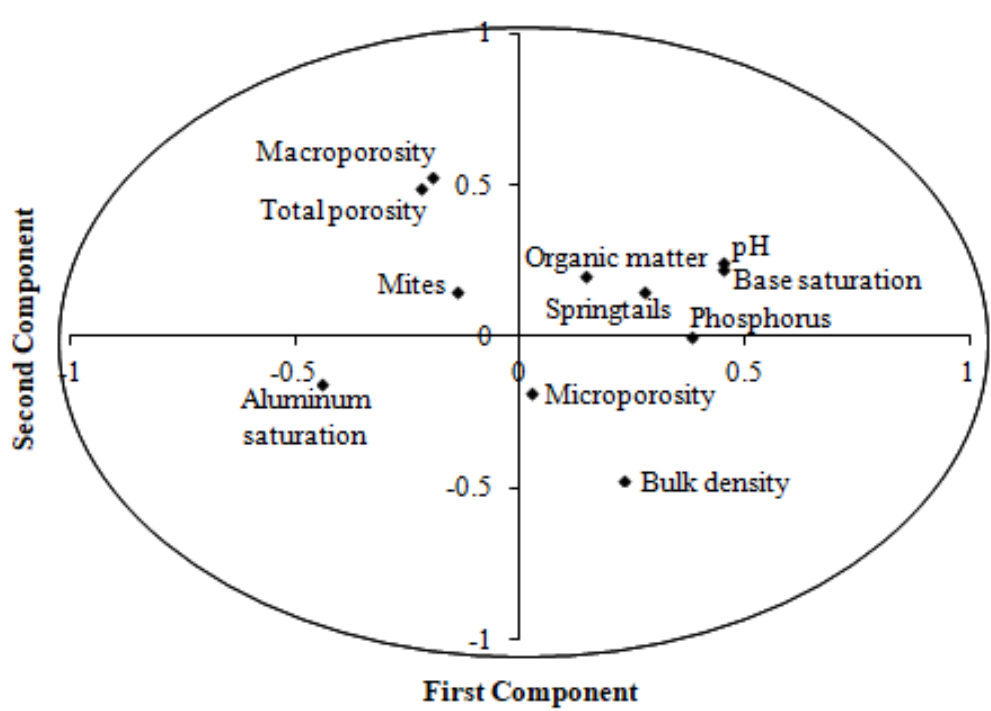

B)

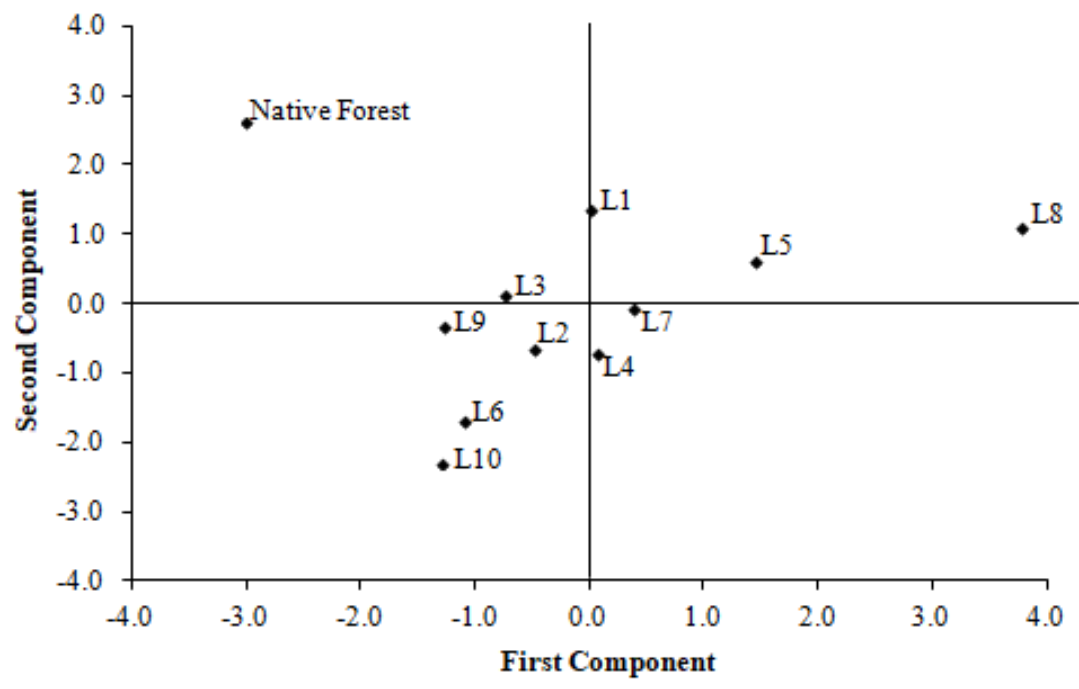

Figure 2. Eigenvectors of biological, chemical, and physical variables of soils under agroecological production (A) and grouping of lots and native forest areas for the first and second components based on biological, chemical, and physical attributes (B).

In the second component, the highest positive correlation was macroporosity, whereas soil bulk density presented the highest negative correlation (Figure 2A). This component can be interpreted by the soil mass/volume ratio since increasing soil bulk density results in decreased soil porosity, especially macroporosity (Brady \& Weill, 2016).

Figure 2B shows the distribution of the studied areas based on the PCA quadrants of the biological, physical, and chemical variables. Considering the quadrants formed by the first and second components, it is observed that the areas L8, L5 were characterized mainly by $\mathrm{pH}$ and base saturation values. Lots L2, L6, L9, and L10 were characterized by aluminum saturation. Native forest soil can be characterized mainly by macro and total porosity. 


\section{Discussion}

\subsection{Soil Quality Status from Settled Farmers' Knowledge}

The definition of the attributes used as quantitative indicators of soil quality was carried out by adopting the following procedures: a) Interviews with farmers about soil quality perceptions and what attributes used for their assessment, organizing them according to the order and frequency of citation; b) Adequacy between the soil attributes indicated by farmers (popular knowledge) and soil attributes based on scientific knowledge, defining a minimum set of indicators, considering aspects of similarity and complementarity. Therefore, the soil quality indicators selected for the present study started from this description, synthesizing the expressions used by farmers in academic expressions.

Settled farmers' responses to the question "What does good quality soil mean?" reveal soil quality indicators mentioned by them were related to morphological (A horizon depth), chemical (organic matter and nutrient content), biological (presence of organisms), and physical (texture, bulk density, and porosity) attributes. In this direction, Adeyolanu et al. (2018) observed that maize/cassava/yam farmers in Southwestern Nigeria identified soil quality through soil compaction, erosion, low drainage (physical attributes), low soil fertility (chemical attribute), and termite infestation (biological attribute). Lima et al. (2013) reported that organic matter content, soil color, and edaphic fauna were the indicators most used by rice farmers in Southern Brazil to define soil quality in production areas. Generally, farmers' assessment of soil quality based on visual observation, and touch involving passing soil through fingers, especially during plowing, to assess the texture, soil organic matter, moisture content, and easiness to plow (Kuria et al. 2018).

Settled farmers' responses to the questions "What cares for preserve soil quality?" and "Does the soil location in landscape influence conservation practices?" showed management systems adopted by farmers consider both the limitations and potentialities of soil types and direct their agricultural practices towards maintaining and improving soil quality. Similar results were observed by Yageta et al. (2019), Buthelezi-Dube et al. (2019), and Kuria et al. (2018), which mention that sloping land, or with drainage problems, or shallow, or intensively used, should be managed with care or avoided due to the possible impacts on crop production and the environment.

\subsection{Technical Soil Quality Assessment}

In the interview, most of the families (seven families) listed the organic matter content as a good indicator of soil quality in their seed production areas. However, the quantitative analysis showed that most areas have low levels with values below or next to $2.5 \%$ (Table 2). This result is attributed to annual tillage adopted by all farmers, which does not allow for the accumulation of cover crop residues in production areas. During the interviews, it was observed that soil tillage is adopted in a more favorable position in the landscape. Similar results were observed by Kuria et al. (2018), in which the importance of postharvest residues under soil was more frequently mentioned by farmers in the recovering landscapes located in more midslope than those in downslope and upslope. 
Although liming was performed in all production areas for at least two years, as explained in the material and methods (Assessment of settled farmers' knowledge), the soil $\mathrm{pH}$ of below 5.5 (Table 2) could be influenced due to the annual addition of poultry litter. Mowrer et al. (2020) observed a similar result, in which $\mathrm{pH}$ decrease after 10 years of poultry litter application in sandy loam soil at 0.20 depths. On the other hand, a positive effect in poultry litter application is increased base saturation in the sandy loam topsoil layer, both under conventional tillage (He et al., 2019), which was observed also in the present study (Table 2).

Considering that poultry litter has around $4 \%$ of $\mathrm{P}_{2} \mathrm{O}_{5}$ (CQFS, 2016), and its availability during the $1^{\text {st }}$ crop (efficiency index of 0.8), the lower phosphorus content in the L5, L7, L9, and L10 areas could be due to the lower clay content of soils (respectively 22, 23, 24 and $20 \%$ ) which promote a low nutrient retention capacity. Additionally, annual soil tillage promotes a greater susceptibility to erosion, which can lead to phosphorus losses, besides organic matter oxidation, a fact observed in the present study (Table 2). Organic matter is crucial in ensuring that the phosphorus present in the poultry litter remains available (when available) in low-clay soils (Brady \& Weill, 2016). In this direction, Bohara et al. (2019) evaluating poultry litter addition in sandy loam packed soil columns observed increased phosphorus concentration in leachate samples compared to soil columns with biochar produced from pinewood chips.

Soil with good infiltration and moisture conservation were indicators of soil quality in the productive areas listed by most families (six families). The quantitative analysis shows a lower bulk density ( 1.23 to $1.38 \mathrm{Mg} \mathrm{m}^{-3}$ ), a higher total porosity (equal or higher $0.43 \mathrm{~m}^{3} \mathrm{~m}^{-3}$ ) and macroporosity (higher than $0.15 \mathrm{~m}^{3} \mathrm{~m}^{-3}$ ) in the agricultural areas (Table 3) probably a reflection of the annual soil tillage carried out for seed crops, according to information from the interviews. Despite the conventional tillage promoting greater soil macroporosity, these are usually agglomerated, more randomly structured, and not connected, whereas in soil under no-tillage the macroporosity can be also higher than conventional tillage, and presented connected pore ramifications, as observed by Galdos et al. (2019).

The most of families (seven families) attributed also the soil organism's presence as a good indicator of quality. However, there were differences in the mites and springtails population between the agricultural areas evaluated. The higher mite population observed in the L1 and L2 areas (Table 4) is possible due to the land's history in the last agricultural year. i.e., before seed crop implantation with soil tillage, L1 was under perennial pasture, and L2 was under fallow land around one year.

More investigations in different seasons and the litter's amount measuring must be carried out for a better understanding of variations in the edaphic mesofauna organisms. In general, the mites and springtails population was low in the areas of agroecological seed production (Table 4), possibly due to the time when the samples were collected (May 2018, early autumn in Brazil). According to Zagatto et al. (2019) in plowed systems, the abundance of soil mesofauna is higher in the winter season and decaying going into summer, and reaching a new increase in abundance in autumn.

The higher mites population observed in native forest area are due to more organic material 
present on the soil surface (litter) which benefits the development of mites. However, similar behavior was expected for springtails, a fact which was not observed in the present study (Table 4). One of the reasons for the higher springtails population in agricultural areas could be attributed to the higher soil acidity, which promotes a more significant development of fungal hyphae (Brady \& Weill, 2016), and is a preferred food of springtails (Oliveira Filho \& Baretta, 2016).

\subsection{Relationship Between Soil Quality Indicators and Soil Management}

There is an association between springtails with soil fertility since they are positively correlated with $\mathrm{pH}$, base saturation, phosphorus, and organic matter (Figure 2A). According to Ortiz et al. (2019), land use systems with less acidic $\mathrm{pH}$, application of organic fertilizers, and maintenance of cultural residues between winter and summer crops favor the presence of organisms of the fauna of the soil, as the springtails, because there are refuges, different alimentary resources which influenced the microbial biomass that serves as food for the springtails.

Springtails and mites were positively correlated with soil porosity (Figure 2A). The porous soil system is a consequence of soil structure, which can be affected by biological processes such as the digging activity of soil organisms and the tangle of particles caused by root growth and fungal hyphae (Ortiz et al., 2019).

In L8 higher $\mathrm{pH}$ and base saturation values, the great springtails number, and the lower aluminum saturation can be explained by the fact that in this area was observed the best soil management (vegetation cover and crop rotation). In L5, although there is no crop rotation, good soil fertility can be explained by the fact that farmers used to observe the crop growth and reinforce the organic fertilization in the areas with lower crop development.

Aluminum saturation observed in lots of L2, L6, L9, and L10 (Figure 2B) is explained by the fact that there is no liming in these areas. Also, in lots 2 and 10 which the area was previously used as cattle pasture and there is no crop rotation; and in lot 6 high levels of aluminum can be explained by the intensive cultivation with two harvests per year.

The native forest area was mainly characterized by higher porosity and lower soil density. This reflects the effect of the forest ecosystem on soil mass/volume relation. The soil porous system is a consequence of soil structuring, which can be affected by biological processes such as the excavation activity of soil organisms and the entanglement of particles caused by the growth of roots and fungi hyphae. In this sense, soils with a higher proportion of porous space than the volume of solids have lower density and, consequently, any factor that influences the porous space will affect the bulk density (Brady \& Weill, 2016).

In general, the integration of biological, physical, and chemical indicators shows that the presence of springtails, soil acidity, fertility, and organic matter were the most prominent variables in the characterization of soil quality under agroecological management. However, of the ten areas evaluated, only two stood out with better values of soil quality indicators. Thus the management adopted by the farmers is agroecological, it is important to know the specifics of each area to obtain better results in soil quality. 
Through the farmers' view on soil quality, several parameters were determined in the laboratory to diagnose the current quality status of the areas with agroecological seeds production of corn, beans, and vegetables. About this, we conclude:

(a) All farmers mentioned that the presence of organic matter indicated good quality soil; however, the study showed that most soils have low content even using cover crops and crop rotation. This is a direct consequence of the annual tillage adopted by all farmers for the implantation of seed crops. However, the annual addition of poultry litter associated with cover crops use possibly contributes to the high base saturation in all soils under agroecological seeds production;

(b) Farmers indicated that a good quality soil would be non-acidic; in turn, soil pH analysis indicated that most of the areas are in inadequate conditions for plant development, with emphasis on L2, L3, L6, L9, and L10 areas, which present toxic aluminum in the range of 5 to $8 \%$;

(c) Uncompacted soil, with good water infiltration and moisture conservation, was listed also by farmers as good quality soil. These conditions were verified in all areas, possibly due to the annual soil tillage before seeds crops implantation;

(d) Farmers pointed out that good quality soil has "life" with the presence of organisms. In our study, we observed a low population of mites and springtails in most areas, and general similar to each other, which should be investigated again in the future to assess the reason for this behavior.

Despite the disparities between the data obtained by analysis and the farmers' perception of good soil quality, it is important to mention that before the conversion to Agroecology, all areas were considered degraded by them. Therefore, the positive farmers' perception mainly about the organic matter content and soil organism's presence in their agroecological production areas come from the degradation history of the areas, at the same time they attribute improvements in soil quality due to the actions adopted over the 10 years, mainly the use of cover plants and organic fertilization.

Finally, farmers who don't practice subsistence farming, should make an agrochemical mapping, to know the particularities of the soil in their farms and to apply methods to improve it.

\section{References}

Adeyolanu, O. D., Are, K. S., Adelana, A. O., Oluwatosin, G. A., Denton, O. A., Ande, O. T., \& Adediran, J. A. (2018). Assessing soil quality issues for crop production function based on farmers' perception: An experience from Itapaji Watershed in Southwestern Nigeria. Eurasian Journal Soil Science, 7, 337-345. https://doi.org/10.18393/ejss.455128

Altieri, M. (2002). Agroecologia: bases científicas para uma agricultura sustentável. Guaíba, RS: Agropecuária, AS-PTA.

Alvares, C. A., Stape, J. L., Sentelhas, P. C., de Moraes, G., Leonardo, J., \& Sparovek, G. 
(2013). Köppen's climate classification map for Brazil. Meteorologische Zeitschrift, 22, 711-728. https://doi.org/10.1127/0941-2948/2013/0507

Bachelier, G. (1978). 'La faune des sols, son écologieet son action': Initiations at Documents Techniques. Paris: O.R.S.T.O.N.

Bardin, L. (2004). Análise de conteúdo. (3rd ed.). Lisboa: Edições 70.

Barrera-Bassols, N., Zinck, J. A., \& Van Ranst, E. (2006). Local soil classification and comparison of indigenous and technical soil maps in a Mesoamerican community using spatial analysis. Geoderma, 135, 140-162. https://doi.org/10.1016/j.geoderma.2005.11.010

Bellon, M. R., \& Taylor, J. E. (1993). "Folk" soil taxonomy and the partial adoption of new seed varieties. Economic Development and Cultural Change, 41, 763-786. https://doi.org/10.1086/452047

Bohara, H., Dodla, S., Wang, J. J., Darapuneni, M., Acharya, B. S., Magdi, S., \& Pavuluri, K. (2019). Influence of poultry litter and biochar on soil water dynamics and nutrient leaching from a very fine sandy loam soil. Soil and Tillage Research, 189, 44-51. https://doi.org/10.1016/j.still.2019.01.001

Brady, N. C., \& Weill, R. R. (2016). The nature and properties of soils. (15th ed). Harlow: Pearson Education Limited.

Buthelezi-Dube, N. N., Hughes, J. C., Muchaonyerwa, P., Caister, K. F., \& Modi, A. T. (2019). Soil fertility assessment and management from the perspective of farmers in four villages of eastern South Africa. Soil Use and Management, 36, 250-260. https://doi.org/10.1111/sum.12551

Campos, B. C., Amado, T. J. C., Bayer, C., Nicoloso, R. S., \& Fiorini, J. E. (2011). Carbon stock and its compartments in a subtropical oxisol under long-term tillage and crop rotation systems. Revista Brasileira de Ciência do Solo, 35, 805-817. https://doi.org/10.1590/S0103-84781998000400006

Caporal, F. R., \& Costabeber, J. A. (2004). Agroecologia: alguns conceitos e princípios. Brasília, DF: MDA/SAF/DATER-IICA.

Casalinho, H. D., De Lima, A. C. R., Martins, S. R., Silva, L. M. S., Cardoso, I. M., De Melo ... Calixto, J. (2017). Construindo uma reflexão coletiva sobre a noção de sustentabilidade a partir de percepções de agroecologia e agricultura familiar. Agricultura Familiar: Pesquisa, Formação e Desenvolvimento, 11, 139-156. https://doi.org/10.18542/raf.v11i1.4682

CQFS-RS/SC - Committee on Soil Chemistry and Fertility. (2016). Liming and fertilization manual for Rio Grande do Sul and Santa Catarina States. Núcleo regional Sul. Frederico Westphalen, RS: Sociedade Brasileira de Ciência do Solo.

Embrapa - Empresa Brasileira de Pesquisa Agropecuária. (2011). Manual de Métodos de Análise de Solo. Rio de Janeiro, RJ: Centro Nacional de Pesquisa de Solos. 
Galdos, M. V., Pires, L. F., Cooper, H. V., Calonego, J. C., Rosolem, C. A., \& Mooney, S. J. (2019). Assessing the long-term effects of zero-tillage on the macroporosity of Brazilian soils using x-ray computed tomography. Geoderma, 337, 1126-1135. https://doi.org/10.1016/j.geoderma.2018.11

He, Z., Tazisong, I. A., Yin, X., Watts, D. B., Senwo, Z. N., \& Torbert, H. A. (2019). Long-term cropping system, tillage, and poultry litter application affect the chemical

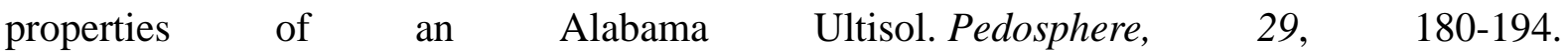
https://doi.org/10.1016/S1002-0160(19)60797-6

Khiel, E. J. (1979). Manual de edafologia. São Paulo, SP: Editora Agronomica Ceres Ltda .

Kuria, A. W., Barrios, E., Pagella, T., Muthuri, C. W., Mukuralinda, A., \& Sinclair, F. L. (2018). 56863 Farmers' knowledge of soil quality indicators along a land degradation gradient in Rwanda. Geoderma Regional, 16, e00199. https://doi.org/10.1016/j.geodrs.2018.e00199

Lacerda Ribeiro, P., Bamberg, A. L., Kunde, R. J., Stöcker, C. M,, Monteiro, A. B., \& Martinazzo, R. (2018). Condições físicas de Chernossolos cultivados com soja na bacia hidrográfica do Rio Santa Maria, RS. Revista Brasileira de Ciências Agrárias, 13, 1-9. https://doi.org/10.5039/agraria.v13i3a5560

Lal, R. (2015). Restoring soil quality to mitigate soil degradation. Sustainability, 7, 5875-5895. https://doi.org/10.3390/su7055875

Lima, A. C. R., Brussaard, L., Totola, M. R., Hoogmoed, W. B., \& Goede, R. G. M. A. (2013). Functional evaluation of three indicator sets for assessing soil quality. Applied Soil Ecology, 64, 194-200. https://doi.org/10.1016/j.apsoil.2012.12.009

Mairura, F. S., Mugendi, D. N., Mwanje, J. I., Ramisch, J. J., Mbugua, P. K., \& Chianu, J. N. (2007). Integrating scientific and farmers' evaluation of soil quality indicators in Central Kenya. Geoderma, 139, 134-143. https://doi.org/10.1016/j.geoderma.2007.01.019

Morshedi, L., Lashgarara, F., Hosseini, F., Jamal, S., \& Omidi Najafabadi, M. (2017). The role of organic farming for improving food security from the perspective of farmers. Sustainability, 9, 2086. https://doi.org/10.3390/su9112086

Mowrer, J., Endale, D. M., Schomberg, H. H., Norris, S. E., \& Woodroof, R. H. (2020). Liming potential of poultry litter in a long-term tillage comparison study. Soil and Tillage Research, 196, 104446. https://doi.org/10.1016/j.still.2019.104446

Oliveira Filho, I. L. C., \& Baretta, D. (2016). Por que devemos nos importar com os colêmbolos edáficos? Scientia agraria, 17, 21-40. https://doi.org/10.5380/rsa.v17i2.48242

Ortiz, D. C., Santos, M. A. B. D., Oliveira Filho, L. C. I. D., Pompeo, P. N., Niemeyer, J. C., Klauberg Filho, O., \& Baretta, D. (2019). Diversity of springtails (Collembola) in agricultural and forest systems in Southern Santa Catarina. Biota Neotropica, 19, e20180720. https://doi.org/10.1590/1676-0611-bn-2018-0720 


\section{Macrothink}

Journal of Agricultural Studies

ISSN 2166-0379

2021, Vol. 9, No. 2

Prudat, B., Bloemertz, L., \& Kuhn, N. J. (2018). Local soil quality assessment of north-central Namibia: integrating farmers' and technical knowledge. Soil, 4, 47-62. https://doi.org/10.5194/soil-4-47-2018

Reichert, J. M., Suzuki, L. E. A. S., \& Reinert, D. J. (2007). Compactação do solo em sistemas agropecuários e florestais: identificação, efeitos, limites críticos e mitigação. Tópicos em ciência do solo. Viçosa, MG: SBCS.

Santos, H. G., Jacomine, P. K. T., Anjos, L. H. C., Oliveira, V. A., Oliveira, J. B., Coelho, M. R., ... Cunha, T. J. F. (2013). Sistema brasileiro de classificação de solos (3rd ed.). Rio de Janeiro, RJ: Embrapa Solos.

Silva, J. B., Casalinho, H. D., de Lima, A. C. R., \& Schwengber, J. E. (2014). Sistemas de manejo em transição agroecológica: Coerências e contradições na prática cotidiana de agricultores familiares. Revista Brasileira de Agroecologia, 9, 98-113.

Soil Survey Staff. (2014). Keys to soil taxonomy (12th ed). Washington, DC: United States Department of Agriculture, Natural Resources Conservation Service.

Tedesco, M. J., Gianello, C., Bissani, C. A., Bohnen, H., \& Volkweiss, S. J. (1995). Análise de solo, plantas e outros materiais. Porto Alegre, RS: UFRGS.

Tesfahunegn, G.B., Tamene, L., Vlek, P.L., \& Mekonnen, K. (2016). Assessing farmers' knowledge of weed species, crop type and soil management practices in relation to soil quality status in Mai-Negus Catchment, Northern Ethiopia. Land degradation \& development, 27, 120-133. https://doi.org/10.1002/ldr.2233

Yageta, Y., Osbahr, H., Morimoto, Y., Clark, J. (2019). Comparing farmers' qualitative evaluation of soil fertility with quantitative soil fertility indicators in Kitui County, Kenya. Geoderma, 344, 153-163 https://doi.org/10.1016/j.geoderma.2019.01.019

Zagatto, M. R. G., Zanão Júnior. L. A., Pereira, A. P. D. A., Estrada-Bonillam, G., \& Cardoso, E. J. B. N. (2019). Soil mesofauna in consolidated land use systems: how management affects soil and litter invertebrates. Scientia Agricola, 76, 165-171. https://doi.org/10.1590/1678-992x-2017-0139

\section{Copyright Disclaimer}

Copyright for this article is retained by the author(s), with first publication rights granted to the journal.

This is an open-access article distributed under the terms and conditions of the Creative Commons Attribution license (http://creativecommons.org/licenses/by/4.0/). 